\title{
Céhes adatok a somogyi pék- és mézesbábos mesterekről az 1810-es évektöl 1869-ig
}

\author{
KNÉZY JUDIT
}

H-1149 Budapest, Pillangó park 16/b. fsz.2., e-mail: jknezy@freemail.hu

\begin{abstract}
KNÉZY, J.: Guild informations about the baker masters and honey-cake makers from 1810 until 1869 in Somogy county. Abstract: During the 18th and 19th century the guilds in Somogy county had developed only slowly because of the lack of cities in the region. The low number of educated baking masters was also based on the fact that the practice of household bread baking remained in existence until the 1960s. Bread baking was made in the 18th and 19th century by seasoned cooksmen and bread specialists. The craftsmen of the markettown Csurgó only got their landlord's approval for creating a mixed crafts guild in 1810. The bakers and honey-cake makers of this town belonged to the so called 'German' guild from 1814. They originated mostly from Austria and the Czeh-Moravian region, some of them were German or Slavic craftsmen from other Transdanubian regions. One or two master worked simultanously in Csurgó. They frequently changed, most of them moved on to the guilds of bigger towns. This study on the life in such guilds is mostly based on the official guild lists and financial documents, it even includes a detailed description of a masterpiece bakery product. The later part of the study gives a rewiev of the life of the baker and honey-cake maker masters in the whole county.by the end of the guild area (1869). The study explaines the growth in the number of such craftsmen caused by the urbanisation and the increased marketing possibilities. It also describes the organisations among the growing numbers of tradesmen including the flour tradesmen supporting the examined crafts guildes.
\end{abstract}

Keywords: baker guilds, the migration of such masters to Southern Hungary, guild lists, guild traditions in Csurgó, bakers and honey-cake makes in Somogy county in 1869.

\section{Bevezetés, a téma indoklása}

A Somogy megyei néprajzi kutatások egyik hiányossága, hogy a pékmesterség történetével eddig senki sem foglalkozott. A muzeális tárgyi gyűjteményekben sem található kutatásra érdemes, datált vagy meghatározott anyag e mesterségre vonatkozóan. Ugyanakkor a mézesbábos mesterség témájából a 20. századi visszaemlékezések alapján történtek adatközlések. Levéltári források felhasználásával csak az andocsi bábosok 19. századi történetéről közöltek eddig adatokat. ${ }^{1}$. Gönczi Ferenc szép számú bábos ütőfát gyűjtött be Nagyatádról (1. ábra), Marcaliból (2.

1 Az eddig publikációkban megjelent ütőfák és bábos céhtárgyak a Rippl, Rónai Múzeum gyüjteményéböl valók Id. Kapitány O. 1980. 169-178. (PI. az itt is bemutatott nagyatádi szarvasos (It.sz 3192.) és két csurgói ütőfát közölt (It.sz 2912, 1916) és egy andocsi utazóládát. Hoss J. 1968. 26-38. négy ütőfát közölt rajzban, köztük az itt látható kakasost (It.sz 5945). Csóti Cs. 2002.162-169. az andocsi vegyescéh tárgyaiból közölt részleteket.

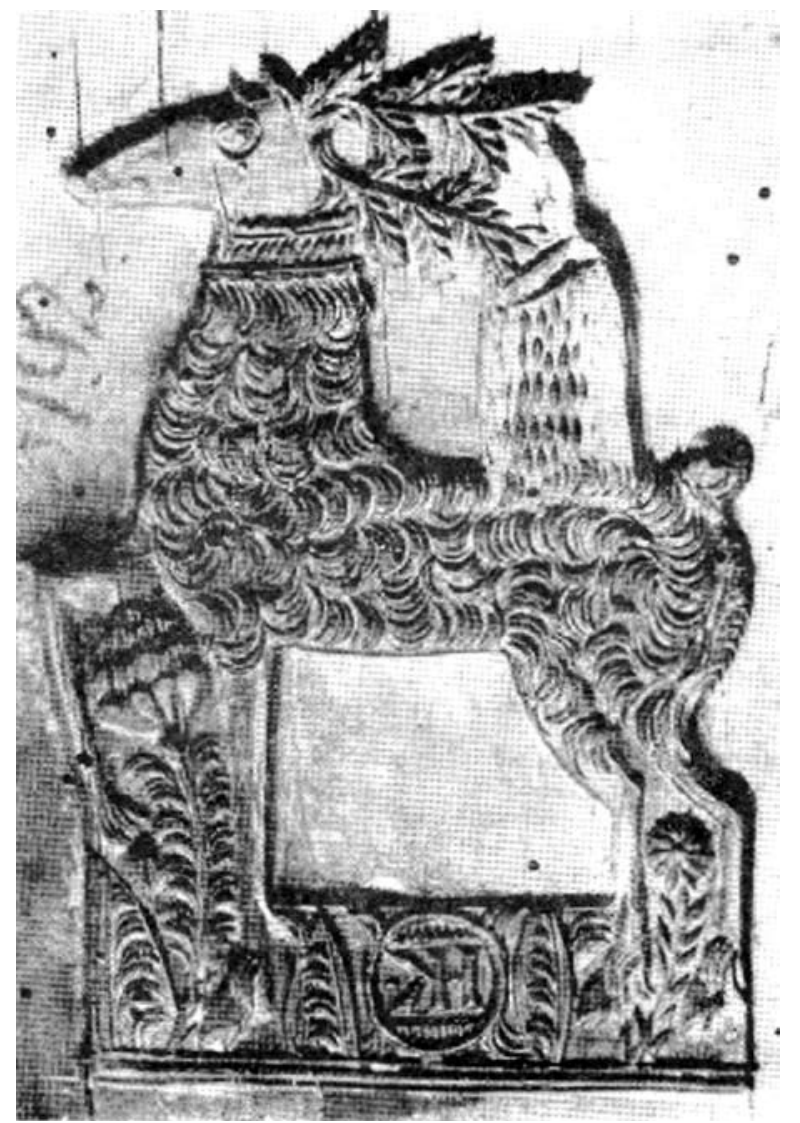

1. ábra: Mézesbábos ütőfa, szarvast ábrázol,

IK monogrammal Nagyatádról Bárány Gáspár mühelyéből, Rippl Rónai Múzeum néprajzi gyüjteménye 3191 It.sz.

ábra), Kaposvárról és Csurgóról (3-4. ábra), stb., a két világháború között. 1963-ban Andocsról Kósa László és Horváth Terézia egyetemi hallgatók egy csaknem teljes bábosmühely berendezésével gyarapították a kaposvári múzeum tárgyi együttesét, közte céhkancsó, behívótábla (1763-as évszámmal) és céhláda is bekerült. Vegyes céhbe tartozhattak, hiszen a kancsón többféle mesterség jelei is találhatók (csizmadia, kőmüves, kerékgyártó, kovács stb). Ez a szerszám- és árukészlet egykor a Dani Sándor és elődei pl. Kopits (eredetileg Kupits néven is szerepelnek) család tulaj- 


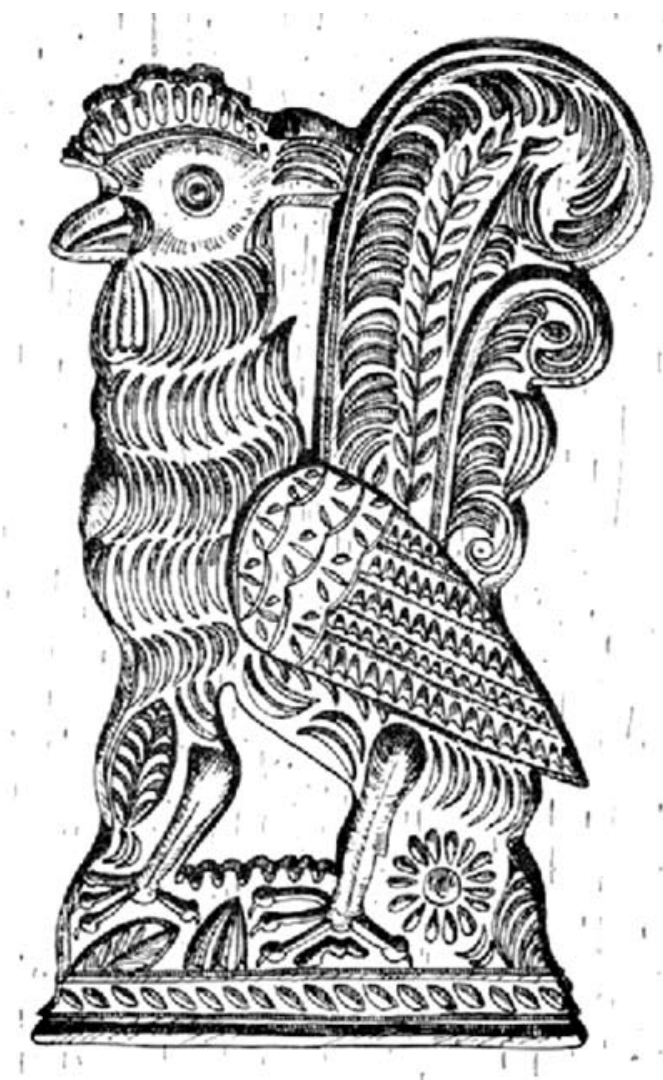

2. ábra: Kakast formázó mézesbábos ütőfa Marcaliból. Rippl Rónai Múzeum néprajzi gyüjteménye It.sz 3845.

donát képezte ${ }^{2}$. A legrégibb évszámos ütőfa Andocsról áll rendelkezésre. Bábos mühelyt először a Zamárdi tájházban mutatott be Kapitány Orsolya 1977-ben nagyrészt az andocsi mühely anyagát. Ennek lebontása után jóval Marcaliban a Helytörténeti Múzeum somogyi kismesterségekről szóló állandó kiállításában 1999-ben újra sor került - többek között - Kapitány Orsolya rendezésében somogyi bábosmesterség eszközeinek enterieur-szerü megjelenítésére. Ez ma is megtekinthető (5. ábra) ${ }^{3}$.

Tanulmányomban két lényegében összefüggő témát tárgyalok: a) Csurgói Vegyes illetve Német céh sütőmestereiröl, bábosairól való adatokat elemzem 1810-1852 közötti céhiratok alapján; b) az 1869-ben történt iparos és kereskedö összeírást ismertetem a Somogy megyei pékekre, bábsütőkre, liszt- és gabonakereskedőkre vonatkozó számszerủ adatokat kiválasztva a többi közül.

$2 \mathrm{Az}$ andocsi vegyes céh kancsója, ládája és 1763-as évszámú céh behívótáblája Id. Knézy J. 2001. 28-29.

3 Sajnos nem készült e kiállítás kapcsán sem tanulmány, sem kiállitásvezető egyik kismesterségröl sem.
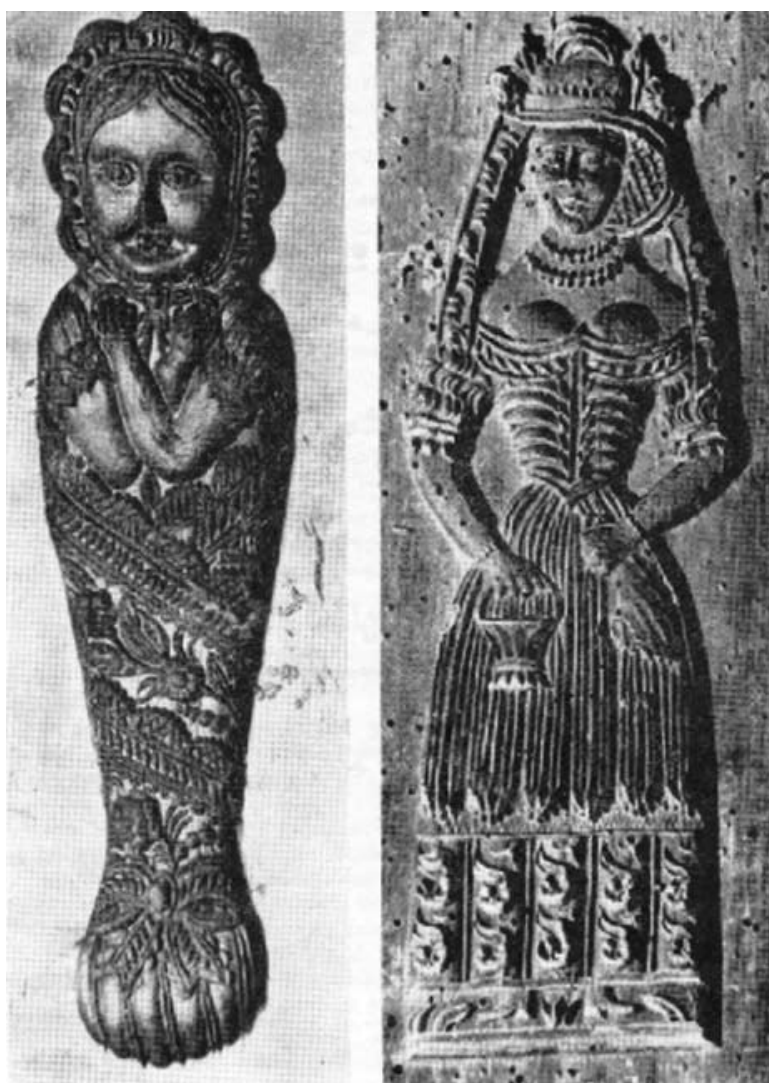

3. ábra: Pólyást ábrázoló mézesbábos ütőfa Csurgóról Valent Imréné mühelyéböl. Rippl-Rónai Múzeum 2912.It.sz.

4. ábra: Kalapos kisasszonyt ábrázoló mézesbábos ütőfa Csurgóról Valent Imréné mühelyéből. Rippl Rónai Múzeum 2916. It.sz.

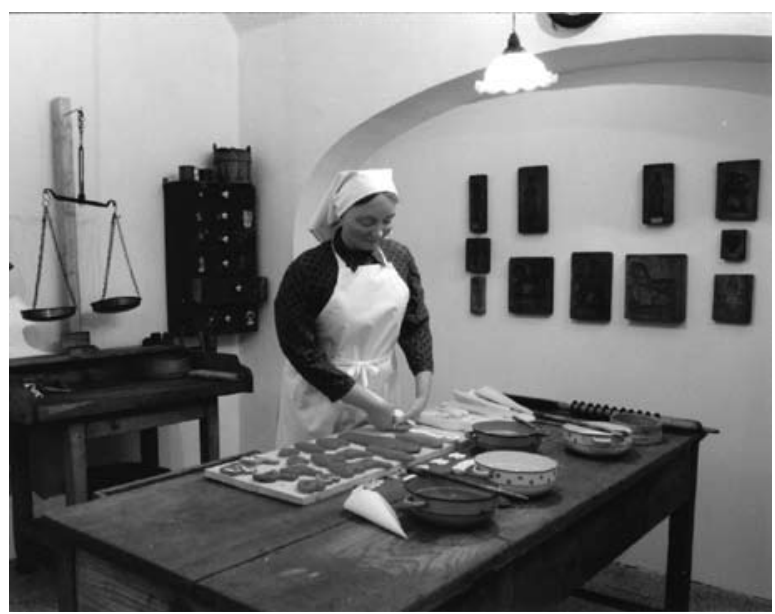

5. ábra: Marcali Városi Múzeum állandó kiállitásából mézesbábos mühelyrészlet Kapitány Orsolya rendezéséböl (1999) 


\section{A nem hivatásos kenyér- és tésztasütők, specialisták tevékenysége}

Dél-Dunántúl azon területek közé tartozik, ahol a városi fejlödés nagyon megkésett. A török hódoltság utáni időszakban aránylag későn alakult meg a legtöbb céh. Különösen jellemző ez a sütőmesterek, pékek megjelenésére. ${ }^{4}$ Azonban Pécs kivételt képez, ott már 1699ben alakult a pékeknek céhe, de általában Baranyában a népesebb és szép számú iparossal rendelkezői helységekben is alig volt 1-2 pék és még kevesebb bábsütő az 1785-86. évi Széchényi Ferenc féle ún. Descriptio szerint. Ezek az iparosok vagy nem tartoztak egy céhhez sem, vagy más helységek céheihez kapcsolódtak. ${ }^{5}$ .A Nagy-Alföldön a XX. század közepéig szerepe volt a sütő háziiparos asszonyoknak, akik ellátták azokat, akik háztartásában nem sütöttek rendszeresen kenyeret. ${ }^{6}$ Ugyanígy a Dél-Dunántúlon is a házi sütésben jártas, de eladásra is gyártó specialisták segítségét kérték a mindennapi vagy ünnepi kenyér készítésére bizonyos munkaalkalmakkor, ünnepen vagy hivatalos személyek étkezésekkor (földesurak, vármegyei, községi, egyházi tb előjárók), ha éppen el kellett látni családjukat, vendégeiket, vagy munkásaikat. Rendszeresen sütögettek piacra, vásárra, búcsújáró helyek közönségének is kenyérsütő asszonyok. A fönemesi konyhán is voltak sütőházak már a 16-17. században is megfelelő képzettségű vagy gyakorlatú sütő-főző személyzettel és segítségeikkel. ${ }^{7} \mathrm{~A}$ köznemesi konyhán is önellátás történt kenyérsütés tekintetében is. A Balaton melléki nyugat-somogyi nemesi lakótelkeken sem hiányozhattak a kenyérsütő kemencék. A finomabb tésztaféléknek kisebb ún. kalács- vagy pecsenyesütő kemencét alkalmaztak az igényesebb konyhán. A reformkorban esetenként módos jobbágyoknál is építettek ilyen kettős kemencéket. $^{8}$

A városokban előfordult tanult pékek letelepedése, esetleg a nagyobb uradalmi központokban is. De a várostalan Somogy megyében sokáig nem nyílt mód városok alakulására. A Dél-Dunántúlon az első pék céhek: Kőszegen 1691-ben, Pécsett 1699-ben, a 18. században Szombathelyen és Kaposváron, 1831-ben Kanizsán alakultak. ${ }^{9}$ A szigetvári („Szigeth oppidum”) 1744. és 1747. évi iparos összeírásában 21-féle iparos szerepelt, köztük említettek péket is. ${ }^{10} A$ megyében lévő nagyobb uradalmak birtokosai családjukkal együtt általában nem tartózkodtak rendszeresen somogyi birtokaikon. Így a sütő-főző asszonyok munkájára a főúr és

4 Dóka K. 2005:178-79.7

5 Papp Zs. 117-133. Siklóson 2 pék és 2 mézesbábos müködött, Dárdán nem volt közülük egy sem, Mohácson 1 bábos, Pécsváradon 1 bábos, 2 pék, Bólyon 1 pék volt stb.

6 Szücs J. 1979: 52-55. szentesi sütőasszonyokról. Juhász A. 1991: 211-12. Szilágyi M. 1998: 423-438. elsősorban alföldi mezővárosok sütőasszonyairól.

7 Búza J. 2005: 178. jobbágyasszonyokat is rendeltek be nagyobb vendégeskedések alkalmával.

8 Knézy J. 1973: 521, pl. Beleznán bári Sigrai birtokán „süteményhez való kis sütőkemence” 1779-ben. 1984 156-7. A somogyszobi Luther u. 24.-ben lévő tájház 1839-ben épült, ebben még megvan a kenyér és kalácssütő kemence is.

9 Domonkos O. 1991:48. 50-53.

10 MOL UC E 156. 50:48, MOL UC E 156. 50:52. családja jelenlétekor, vendégek érkezésekor volt szükség, elöfordult, hogy hivatásos szakács vagy felfogadott konvenciós belső cseléd, főzőasszony gyakorlattal rendelkező személy látta el ezt a feladatot. Pékek csak a 19. század elejétől szerveződtek Somogyban helyi céhekbe, de nem önállóan, hanem vegyes céhekbe. Elöfordulhatott, hogy a beköltözött sütőemberek valamelyik távoli, esetleg más megyéből való céhbe jelentkeztek be, de a jobbágyrendszerben lakóhelyükön mindenképpen az uradalom kötelékébe kellett, hogy tartozzanak. Nagyon valószínü, hogy a lisztet is az uradalmi raktárakból kellett vásárolniok ebben az időben. ${ }^{11} \mathrm{Az}$ uradalomhoz tartozó zsellérekként béreltek telket, azért és a robot megváltásáért is fizettek évente pénzt ${ }^{12}$. A kenyér, péktermék készítéséért az uradalom külön fizetett, de a vásárok, piacok helypénzei az uradalmak jövedelmeit növelték. Nagyatádon Czindery Ignác az ott megfordult, vagy ott élő pékektől a kenyerek sütése után 1750-ben 28 ft 60 krajcár évi jövedelmet nyert. E fenti irat nem használta a sütőasszony elnevezést, így tanult pékekről lehetett szó. A nagyatádi az 1775-ben alakult vegyes céhnek még nem volt tagja sem pék, sem bábsütő mester. Készültek uradalmi, de országos összeírások is a 19. század elejétől az iparosokról. 1809-ben készített uradalmi iparos jegyzékben Nagyatádon már volt egy bábos, de pék nem..$^{13}$ Marcaliban 1828-ban már számba vettek egy péket. ${ }^{14}$ Andocson is a búcsúk miatt a 19 . század első felében már tevékenykedtek bábosok. ${ }^{15}$ Nemcsak a pékek megjelenését megelőzően, de később is velük párhuzamosan szerepe volt a kenyérsütő háziiparos „sütögető, sütkérező, vagy kenyérsütő” aszszonyoknak. Felkérésre, vagy rendszeresen készítettek kenyeret eladásra. Milyen alkalmak lehettek ezek:

1. Hivatalos étkeztetések hivatalos ebédek, vacsorák (úriszékek vagy más peres alkalmak tisztviselői, határjárások, mezővárosok tisztségviselőinek látogatói, vármegyei küldöttek, egyházi vizitációk végzői, az uradalmak távolról jött tisztviselői, vagy felkért máshonnan érkezett fontos szakemberei számára esetenként külön kértek fel sütő-föző asszonyokat, hogy lássák el őket. Ezeken az alkalmakon is elöfordult, hogy „házi kenyeret” süttettek, vagy zsemlét, fehér kenyeret szereztek be pékektöl, zsemlét esetleg leves sürítésre is. A „a házi kenyér”, a köznép kenyere Somogy legnagyobb részében rozslisztből készült és barna színü. ${ }^{16}$

2. A helyi földesúri majorok vendégeinek, az egyénileg az uradalom más birtokairól érkező munkavállalóinak (kereskedők, iparosok, ügyvédek, földmérők, árokmetszők, üvegesek, kéményseprők), ügyfeleknek, de még a vendéget, szakembert szállító ko-

11 Papp Zs. 2001. 122. írta le, hogy Baranya megyében a pékek a bellyei, vajszlói illetve a dárdai uradalomból vásárolták a lisztet.

12 Knézy J. 1997: 147. Dóka K. 2005: 213-4

13 Gözsy G. 2001: 145-6, 153. A közeli Segesd búcsújáróhely miatt volt ez fontos

14 Knézy J. 1991:468

15 Csóti Cs. 2002. Céhes tárgyak is kerültek be a Rippl-Rónai Múzeumba 1963-ban, láda, kancsó, behívótábla, de a behívó táblán kívül készítési idejük még nem megállapított, készítési helyük sem.

16 Knézy J. 1984: 140. MOL Széchenyi cs. It. P 623. IV. k. 4. sz. 23.cs. Dominium Csokonya 
csisoknak is a földesúri konyhán adtak meleg ételt, kenyeret és italt. Csurgón pl. a képzett és írni is tudó Stiess Josepha készítette el az ételt és tartotta számon a kiadásokat a vendégek diárumában. ${ }^{17}$ A balatonmogyoródi Széchenyi uradalom szakácsnője az ellátott vendégek rangja, beosztása szerint háromféle mennyiségü összeget fordíthatott a háromféle minőségű ételsorra - mutatja a számadása. ${ }^{18}$

3. A céhes mestereknek is voltak olyan ünnepei, vagy hétköznapi találkozói (a céh szentjének ünnepe, temetések, vidéki Landmeisterek megjelenése a céh eseményein, ebédjük, uzsonnájuk stb), amelyeknek lakomáját a céh kasszájából fedezték. Hivatásos pékektől is vásároltak pl. zsemlét, fehér kenyeret. Házi kenyeret is megrendelhettek meleg ételek mellett helyi vendéglősöktől, másoktól. A sütés-fözés sok esetben a céhmester feleségére maradt, míg férje viselte tisztségét, e munkát az asszony térítés ellenében végezte el. Az ő kezére adták a nyersanyagokat (pl. lisztfélét, húst). A Csurgói Külső illetve Német céh protocollumában több ilyen kiadás szerepel. pl. 1815-ben „semlye hozatott Atádról 5 forintér... 1816-ban egy házi kenyér 4 forintért...1819ben külső mestereknek napjára borért, húsért és semlyéért 57 forint,, került kiadásra. „1821-ben Úr napjára Péktöl semlyét 1 for $5 \mathrm{xr}$,-rt ... egy házi kenyeret...a vendégfogadóból”...vettek. ${ }^{19}$

4. Mézesbábot nem vásároltak az iparosoknak a napló szerint a bábostól, de annál inkább gyertyákat, amelyért rendszerint a kanizsai báboshoz fordultak pl. 1818-ban Schpraizenbrait Mátyásnak „duplérért” 60 forint 39 krajcárt fizettek, „áldomást” is adtak neki kétszer is. ${ }^{20}$

5. Piacok vásárok közönségének ellátásaként került sor pecsenyesütők, kenyeresek tevékenységére. Magyar Eszter írta le Szántódpuszta kapcsán, hogy voltak"sütkérező asszonyok" Köröshegyen, Szárszón, akik árulták termékeiket, de sertést is feldolgoztak, valószínü sült húst is árultak a szántódi rév környékén megfordulóknak. ${ }^{21}$ Richard Bright leírta, hogy vásáron rozscipókat árultak sütőasszonyok Veszprémben, portékájukat a fejükön szállítva, említette, hogy ilyen kenyeret üzletben nem lehet kapni. ${ }^{22}$ A somogyi vásárokon házikenyeret árulók éppúgy előfordultak, mint pékek. A kaposvári vásári limitációk közül az 1759-es még nem foglalkozott pékáruk árazásával, de 1772ben kiadott árszabásban már 1 font fehér kenyér 6 , 1 font fekete kenyér 3 dénárral szerepelt. 1813-ban „négylatos mont zsemle és hétlatos közönséges mont zsemle” is szerepelt 1-1 krajcár árral, „fekete és fehér kenyér fontjának" ára és mindezekhez való háromféle

17 MOL P 276 Festetich cs. It.IV. Kp.-i birtokgazdálkodás. Számadások 602. cs. 35.p.

18 Magyar Mezőgazdasági Múzeum Adattára Al (eredeti iratok gyűjteménye) 184 Interveniens diárium 1818.

19 Somogy megyei Levéltár (SML) Testületek, céhek IX. 3. Csurgó Külső ill. Német céh kiadási és bevételi naplója 1810-től kezdve pp. 41. 51. 60.

20 SML IX. Csurgói céhek 3.sz. Bevételi és kiadási napló. Külső céh 41.p. 51.p.

21 Magyar E. 1984: 54.

22 Bright, R. 1815/1970: 85. liszt árazása is megtörtént. ${ }^{23}$. Karádon kenyér- vagy kalácsárusok fizettek helypénzt gyalog vagy kocsival, Toponáron 1830-ban „czipóáruló”, Sárdon pék is rész vett. ${ }^{24}$ Pereceseket, pogácsásokat, lepényeseket nem emlegettek e vidéken a helypénzjegyzékek.

6. A kisebb beálló kocsmákban csak italt kaptak az utasok. A nagyobb vendéglátóhelyek esetében, ahol meg is aludtak a vendégek, a bérlö kötelességévé tette a földesúr, hogy a vendégeket minél körültekintőbben lássák el: "mivel a konyhabéli haszonvétel hasznára szolgál, minden igyekezettel azon legyen, hogy az utasokat beszállásra szoktassa." ${ }^{25}$.

7. A felfogadott időszaki munkásoknak a szerződésben többnyire nem kész kenyeret ígértek, hanem gabonát biztosítottak, így: 1773-ban „csurgói majorból kenyér és főzelék fog kiadatni az aratóknak, melyben ők ételt tartozni fognak készíteni magoknak, szakácsnéjoknak fog kiadatni egy köböl kenyérnek való, s midőn magok részét fognak csépölni egy köböl kenyérnek való gabonát...is" Cigány munkásoknak viszont adtak kenyeret fizetségképpen. ${ }^{26}$

8. Említendő a molnárok sütőtevékenysége is, bár most nem témám, akiknek földesurukat kellett esetenként ellátniuk még a középkorban is. A 18-19. században a hosszú ideig lisztjükre várakozó parasztokat esetenként kelesztetlen lepénnyel helyi általános nevén „sóspogácsával” lepték meg pl. Dél-Somogyban, a Dráva menti malmokban is. Ennek a kenyérlepénynek néhol épp e szokás miatt „molnárpogácsa”, „mónárpogácsa” is volt a neve 20 . századi emlékanyag alapján. ${ }^{27}$

\section{A pékekre, bábosokra vonatkozó céhes adatok a Külső azaz Német Céh protokollumaiban}

A csurgói uradalomban hivatásos pékröl nem találtam adatokat a 18. század végi számadásokban, de vásároltak atádi, kanizsai péktől zsemlét, fehér kenyeret, de még a felkért bábos is vagy kanizsai vagy nagyatádi volt ebben az időben. ${ }^{28} \mathrm{~A}$ pest-budai mézeskalácsosok céhéhez, mely 1719-ben alakult csatlakoztak idővel a nagykanizsai (1728), pécsi (1823), marcali, keszthelyi, nagyatádi, kaposvári vidéki mesterek. ${ }^{29} \mathrm{~A}$ kaposvári mézesbábosnak szinte egyeduralma volt Somogy megyében a 18. század folyamán, minden sokadalmon megfordulhatott, csak mikor Kanizsán is ki akart „rakódni” a vásáron, a kanizsai bábos azt megakadályozta. ${ }^{30}$ Pék céhek a megye környékén Pécsett 1699-ben, Kőszegen 1691-ben, Szombathelyen, Kaposváron a 18. század folyamán, Kanizsán 1831-ben alakultak. ${ }^{31}$

23 SML Protocollum generalium et particolorum 1759. okt.23, 1772. 1813 nov. 13.congregationum 17

24 SML Mernyei uradalom irattára. Vegyes számadások. 1820-30.

25 MOL Széchenyi cs. It. IV. k., 13. sz. Possessio Látrány

26 MOL P 276. IV. 1771. 600. cs. 42-43, 1773, 602.cs. 15, 19, 41, 68.3. cs. Számadások „kenyér kiadása naponként aratóknak, szénagyüjtőknek..., hízlaló legényeknek”. Knézy 1997. 164.

27 Mike Gy. 1968: 11. Lábodon és a Dráva menti malmokban

28 MOL P 276. V. 602. 3.sz.

29 Dóka K. 2005. 213.

30 Kiss I. 1962. 82-93.

31 Domonkos O. 1991. 50-53. 
1810-ben kapott a Csurgói Vegyes Céh a Festetich Györgytöl kiváltságlevelet, amelyhez föként az uradalom területére eső falvak mesterei tartoztak, de nem kizárólagosan. Ugyanazt az alapító levélszöveget küldte el, mint a többi nyugat-magyarországi birtokaihoz tartozó keszthelyi, vasvári, csáktornyai vegyes céheknek is. Ebben a szövegformulában bábsütő és zsemlesütő mesterség is szerepelt. ${ }^{32}$ Csurgón zsemlesütőt nem, csak „sütő” vagy „pék” mestert emlegettek, ezt sem következetesen, és nem szerepelt sem a fehér, sem a fekete jelző, sem a pereces megjelölés. A vegyes céh 1815-ben kettévált, a pékek és bábosok a Csurgói Külső illetve a Német Céhbe tartoztak attól kezdve. Az utóbbi céhben visszamenőleg vezették 1810-től a remekes mesterek jegyzékét. észrevették a pontatlanságokat és 1829-ben újra írtak jegyzéket a „remekes mesterekről” 1810-től kezdve. Voltak bevételi és kiadási naplók, adósok jegyzéke, a céh rendelkezéseiről való bejegyzések, inasok felvételének jegyzőkönyve, esküvések szövegei stb. Az iratanyag nem folyamatos, kisebb-nagyobb időbeli megszakítások vannak, illetve néhány lap hiányzik. A felhasznált források még nem szerepeltek a magyarországi céhkataszterben, mert annak megjelenése után kerültek át más iratanyagokból a Somogy Megyei Levéltárban a „céhek, testületek irat együttesébe, ahol külön csurgói céh és csurgói ipartestületi anyag is van. ${ }^{33}$ Utóbbival nem foglalkozom. Elsősorban a céhes mesterekre vonatkozó meglévő adatok alapján kísérlek meg összefüggéseket feltárni, más iratanyagokkal (pl. anyakönyvek, vármegyei közgyűlési jegyzőkönyvek stb.) még nem sikerült egyeztetni ezeket a szórványadatokat. Figyeltem a neveket, származást, vallást, mesterségük elnevezését, a befizetések mibenlétét, a mesterremekelés eseményét, a jelzett tisztségeket, inas fogadás tényét, vétségeket és a távozási bejegyzését, ha volt ezekre adat. Valószínűnek tűnik, hogy a céhbe felvételt kérő két péknek is - mint később kiderül - korábbi helyén gondjai lehettek, mert itt is lopást bizonyítottak mindkettőre, egyik pedig az inasát is lopásra tanította. De a bírságpénzt kifizették és maradhattak.

Rippentinger János katolikus pék már 1810-29 között szerepelt Csurgón a remekes mesterekről írt mindkét jegyzékben, aki Földvárról, Tolna megyéből érkezett. 1929 után Atádra költözött. 1814-ben már nótárius címet érdemelt ki, 1815-ben fizette le kapitálisát, 1821ben inast is fogadott. Valószínű az 1828. évi országos összeírásban ő a feltüntetett egyetlen csurgói pék. ${ }^{34}$

32 Somogy Megyei Levéltár Csurgói céhek IX.3. 1810. Ld később részletesebben.

33 Céhes anyag:

I. „Remekes mesterek jegyzéke 1814-27, 1-17.p

II. Remekes mesterek jegyzéke 1829-40. 29-31.p. Újra számbaveszi

az 1810 óta még ott dolgozókat s az újakat.

Bevételi és kiadási napló 1814-27. 29-31.p.

Adósok lajstroma 1812-38. 85-89.

A külső céh cselekedeteiről és végzéseiről való prot. 92-144

Bevételi és kiadási könyv 1827-39. 146-192. p

Inasok jegyzéke 1815-1840. 194-211.p.

Eskük, regulák szövege é.n. 220.p.

Sterle János céhmester bevételei 1851-52. 19-27.p

1852. évi összeírása a külső céh mestereinek

34 SML IX. 3. I. Remekes mest.jegyzéke38.bejegyzés, Kiadás bevétel 47. mesterremekért Büntetés ügyek 110.p Inast fogadott 211.p.90.p. és kiadás és bev. 63.p.
Schmid Dávid (később Dánielként is irták) evangélikus pék 1811 mác. 25 és 1832 között volt Iharosberényben a remekes mesterek körében. 1816ban szolgáló mesternek választtatott, 1818-ban készített mesterremeket, ennek hibáiért $7 \mathrm{ft}$-ot fizetett. 1824-ben lopást bizonyítottak rá „polkát megölvén megette, de egyebet is eltulajdonított Szabó Gergely professzortól”, sőt a lopást felfedező „Kerekes Dávid bognármestert ok nélkül simfelte". 1826-ban inast fogadott Kaposújlakról. 1832-ben átköltözött Nemesvidre. ${ }^{35}$

Schifhorn János evangélikus sütő Berzencére költözött 1814-ben fél taxát fizetett. ${ }^{36}$

Dastristein Jakab kőszegi sütő 1820-ban jelentőt fizetett, fél taxa mellett beálláskor mesterlevélért 7 for. $5 \mathrm{xr}$-t, egy vándorkönyv bezárásáért $3 \mathrm{xr}$-t. ${ }^{37}$ Kőszegen volt pék céh, mégis itt jelentkezett, talán a fél taxa miatt.

Viola Antal bábsütő 1821. jún. 2. én Csurgón fizetett jelentő pénzt, 1 forintot. Többszöri figyelmeztetés ellenére sem mutatta be tanuló és bábos levelét. 1826-ban inas szegődött hozzá ${ }^{38}$

Jakob Untergasse pék Böhönyére a tiroli Taufersdorfból érkezett 1825. júl. 2.-án, 1 forint jelentőt és inasa elszegődéséért 2 forintot fizetett ${ }^{39}$. A következő évben Becsehelyre költözött át.

1826-ban Nagy Lajos 13 éves kaposújlaki református fiú szegődött el pékinasnak a fent említett Schmid Dánielhez 4 évre. A mester vállalta, hogy csizmát ad elegendőt, a szegődő- és szabaduláspénzt egyszóval minden költségét fizeti. Keresztatyái Himler és Fábián nevü mesterek lettek. ${ }^{40}$

Kölbl József református pék Szigetvárról a csurgói céhhez folyamodott felvételért. 1829. jún. 29.-én fizette be a $12 \mathrm{ft}$ taxát mester volta elfogadásáért. ${ }^{41} \mathrm{Kölbl}$ József vagy azonos nevű szintén pék utódja pék 1869ben is müködött Szigetváron.

1830-ban a csehországi katolikus Haulitsek (szerepel Holicsek néven is) József nevű pék jelentkezett be Berzencére. 1831. március 5.-án Csurgóra ment, készített mesterremeket sok hibával, de pénzzel megváltotta. 1832-ben megbüntették, mert a „céhmestert pörcös termetűnek szidta, s az inasát lopásokra tanította... megbizonyosodván a panasz napvilágra jött”, fizetett 4 ft bírságot. 1843-ban Barcsra ment lakni. ${ }^{42}$

1836. szept. 2.-én Nemesvidről a zsidó vallású Fidei Ábrahám sütő fizette be a Landmeistereknek kötelező fél taxát. ${ }^{43}$

35 SML IX. 3. sz. Remekes mesterlista 1811. 13. bejegyzés 1829 29.p. Mesterremek 1818 -ben Bevétel és kiadás 47.p. Lopás miatt a Külső. céh végzéseiröl prot. 110.p. Inasok jegyzéke 1826. 90.p. és befizetések 63,p.

36 SML IX. 3. Bev. és kiadási prot 173. p

37 SML IX: 3sz. Remekes m. 1814-27.

38 SML IX. 3. sz. Prot. Kif. és bef. 1821. 60.p. Külső céh végzései 1821 103. 106. és 113.p. Inasok lajstroma 90.p.

39 SML IX. 3. sz. Mesterek jegyzéke 129. bejegyzés. Ki- befizetések. 76.p.

40 SML IX. 3. sz. Inasok Lajstroma 1826 90. p. 211 bejegyzés

41 SML IX. 3. sz. Kif és bef. jegyzéke 137. p.

42 SML IX. 3.sz. Mesterek jegyzéke 148. bejegyzés. Bevételi és kif. jegyzék 124. 1827-39- 148.p.

43 Mesterek jegyzéke 179. bejegyzés. 1827-39. 
1837. máj.25.-én Berzencéröl a katolikus Schifhorn János sütő jelentkezett be a céhbe. ${ }^{44}$

1838. márc. 10.-én Beleznáról a csehországi pék Hutsek József került jegyzőkönyvbe. ${ }^{45}$

1840-ben Flengl József inasnak került Berzencére sütőinasnak Stevlicsek mesterhez, aki minden költségét fizette a céh felé.

1840.ápr 17.-én érkezett Hablicsek József nevü sütő Csehországból Csurgóra. ${ }^{46}$

1850-ben Prager Maximilian kanizsai sütő szegődésért, szabadulásért, tanuló levélért és vándorkönyvért 4 ft 54 krajcárt fizetett. ${ }^{47}$

1851-ben a kőszegi sütő Dastristen Jakab jelentéskor fél taxa mellett beállásért $7 \mathrm{ft} 5 \mathrm{kr}$-t fizetett. Mesterlevelét bemutatta. ${ }^{48}$

1851-ben Schmid Jakab beírót fizetett 28 forintot ${ }^{49}$

1852-ben a külső céh iparosainak összeírásában egy sütő, Bíber József és egy bábos, Hanslitsek Mihály szerepelt. Hanslitsek Mihály még 1869-en is Csurgón tevékenykedett. ${ }^{50}$

1810-52 között 8 helységben 14 fö (4 „pék” és 10 „sütő”) mester, egy mézesbábos helyezkedett el különböző időre mint mester, vagy vált mesterré. Csurgón egy-egy időben 1-1 sütő volt, a többi vidéken dolgozott. A legmesszebbi „vidéki” mester szigetvári, kőszegi és kanizsai pék volt. A legényeknek nem találtam jegyzékét, az inasokét vezették 7 fő adatai tünik biztosnak, ebből egy Kaposújlakról, egy Atádról, egy Marcaltőről, egy Németvárról és három Kanizsáról érkezett. Az inasok lajtromában sok a pontatlanság, sokszor jóval a munkába állás után kötöttek velük szerződést. ${ }^{51}$

Pék mesterremek leírás egy található a bevételi naplóban, az is azért, mert sok hibát követett el a pályázó: 1831-ben Holitsek József korábbi berzencei pék Csurgón lakva remeket kívánt készíteni zsemlyét, kiflit és perecet egyforma mennyiségút 20 font lisztböl sütve 4 lat nehézségüt. Megvizsgálás után tapasztalták"1. A liszt mennyiségét nem találta el, a 20 font lisztből megmaradt 7 font, 2. A zsemlye több lett 2 és fél lattal 3. Gerezdes és hosszú zsemlét nem tud sütni. 4. A kiflik proportio nélkül vagynak. 4 hibákért $6 \mathrm{ft} \mathrm{taxa}$, a zsemléket az érdemes céhnek ajánlja és ezenkívül fizet $2 \mathrm{ft}$... Úgyis a mester lányát vette feleségül" ${ }^{52}$ - megjegyzés mutatja, hogy a benősülöket mennyire kevésbé vették szigorúan szakmailag és anyagilag sem terhelték meg annyira.

Ladon az akkor alakult egyesült céhben mesterként szerepelt 1848.-ban Jánszky József pék is, akinek a neve később (pl. 1869-ben) nem bukkant fel. ${ }^{53}$

\footnotetext{
44 u.ott. 183. bejegyzés.

45 Bev és kifizetési napló 1827-39. 183.p.

46 U.ott Mesterek jegyzéke 73. bejegyzés

47 SML IX. 3.sz. Sterle János céhmester céh bejegyzései 1851-52. 34. tétel.

48 Remekes mesterek II. lajstroma 39. tétel

49 Sterle Jakab céhmester céhjegyzéke 1851-52. 24. bejegyzés 19.p.

50 SML IX. 3. sz. a Csurgói Külső céh mesterembereinek jegyzéke táblázatban 1852

51 SML IX. 3.sz Inasok lajstroma 1810-1840. 194-211.p.

52 SML IX. 3. sz. bevételi és kiadási jkv. 124. p.

53 SML IX.19. Sz. németladi egyesült céh iratai 1848-1861.
}

Az összeírások számadatai keveset árulnak el az iparosokról. Csurgón 1828-ban egyetlen péket említettek és egyetlen bábost. Ebben az évben vált külön a berzencei vegyes céh, de a pékek és bábosok továbbra is a csurgói anyacéhhezhoz tartoztak. ${ }^{54}$ Ebböl is látszik, hogy a számszerü adatok mindig statikus állapotot mutatnak, nem jelzik a mozgást, változást. Marcaliban is csak egy péket jegyeztek fel 1828-ban, bábost nem. ${ }^{55}$

A csurgói Német, azaz Külső céh 1852-ben készített egy táblázatot mestereiről. Ekkor 29 helység 22 féle mesterségének iparosai tartoztak a német céhhez, összesen 131 mester és legény, ebből Csurgón a központban 53 fö dolgozott, köztük egyetlen pék és egy bábos, akiknek már említettem a nevét. A Csurgói Belső Céhnek nem maradt fenn ebből az évből összeírása.

A csurgói iparosok igen jelentős része származott Csehország területéröl mind a 18, mind a 19. században. Az iparosok lakta két utca közül az egyiket ezért is nevezték Cseh utcának. (Ma Eötvös utca). 1852-ben több céh - többnyire vegyes céh - volt már Csurgó környékén, Berzence mellett, Fazekasdencsen, Miháldon, Tapsonyban és Böhönyén is - mutatja a csurgói külső céh iratanyagában az abban az évben küldött rendelet bevezető szövege. ${ }^{56}$

1868-ban összesen 131 adófizető iparost és kereskedőt tartottak Csurgón számon. ${ }^{57}$ Csurgón csak egyetlen pékmestert (Vanicsek Lajost) és egyetlen bábsütőt jegyeztek fel (Hanslitsek Mihályt, aki már 1852-ben is itt dolgozott. Vanicsek nevüek még ma is laknak Csurgón. 1868-ban már a Csurgói Külső Céhhez korábban tartozó helységekben, ahol Landmeisterek dolgoztak 8 sütömester dolgozott (Szigetváron három, Berzencén kettő, Iharosberényben, Nemesdéden és Nemesviden egy-egy. Bábsütő Csurgón kívül egyedül Szigetváron tevékenykedett, de ott kettő is. 1876-ban egyedül Csurgón két sütő és egy bábos mestert tartottak számon. Az összes iparos és kereskedő száma ekkor e helységben 145 fő. ${ }^{58}$

\section{Az 1869. évi Somogy megyei iparos és kereskedő összeírás pékekre, bábsütőkre, gabona és lisztkereskedőkre vonatkozó adatai}

1860-as években két sikertelen szavazás volt a megyében, mindkettőt megelőzte az iparosok és kereskedők összeírása. Tanulmányomban az 1869-es jegyzéket elemzem, mely meg is jelent és elég teljesnek látszik. ${ }^{59}$ A szavazási joggal rendelkezőket, (akiknek állandó lakhelyük, saját mühelyük volt és legalább egy legénnyel dolgoztak), a vármegye íratta járásonként öszsze a jegyzőkkel a soproni iparkamara elrendelésére. Azselickisfaludi jegyző feljegyezte véleményét arról, hogy Somogyban az iparosok inkább csak a téli időszakban foglalkoznak szakmájukkal, nyáron inkább mezőgazdaságban tevékenykednek. A korábbi adatokból is kiderül,

\footnotetext{
54 MOL U et C E 156 1828-as Regularis conscriptio. ídézi Horváth J. 2005. 158-159.p

55 Knézy J. 1991. 461

56 SML IX. 3.sz. 1852

57 Récsei B. 2005: 135-143,154-155. Marcali és Szigetvári járások

58 A soproni iparkamara... 1876. évből 544-678. Horváth J. 2005:

59 Récsei B. 2005: 77-179. összeírás alapja
} 
hogy az iparosok eljártak aratni, csépelni, de főként arra törekedtek, hogy legyen egy kis szőlőjük, ahol a konyhakerti növényeket is megtermelték. Az ügyesebbje lovat is szerzett, hogy ne szoruljon fuvarosok munkájára. A télre korlátozódó iparos munka a pékekre, bábsütőkre kevésbé vonatkozhatott, mert ugyan nekik is lehettek kampány időszakaik, de kisebb kihagyásokkal legtöbbjüknek nagyjából egész éven át akadhatott munkájuk. ${ }^{60}$ Ekkor még ide tartozott a szigetvári járás is. Feltüntették az egyes helységek lakóinak számát, az iparosok és kereskedők együttes számát, a nevüket, szakmájukat is. Megtudjuk, hogy egy-egy helységben név szerint és mesterségük szerint milyen iparosok, kereskedők és magánzók éltek. Egyes járásokban az adózásuk mértékét is feltűntették. Az igali járás egy részében jelezték csak a legények számát egyegy legény Szil két pékénél és bábsütőjénél, más járásban nem. Általában a sütő nevet tüntették fel öt esetben péket. Itt ekkor zsemle és fehérkenyér készítőt jelentett a pék. A pékek, sütők nagyobbrészt német, bajor esetleg cseh, morva nevüek, alig akad köztük magyar nevü.

Az 1829-68 közötti időből a csurgói céhben dolgozók közül a szigetvári a Kölbl család tevékenysége lehetett folyamatos, 1840-1869 között több helyen ismertek a Hanslitsek, illetve Holicsek nevüek csehországi származással, köztük pékek és bábosok is előfordultak, mint Hanslitsek Mihály bábos 1852-ben és 1869-ben.

Észrevehető 1869-ben, hogy ahol több pék tevékenykedett, ott rendszerint gabona- vagy lisztkereskedők is laktak. Előfordult, hogy a pék egyben vegyeskereskedő is volt, így Szilben és Nemesvíden. 310 helységet vettek számba, 291-ben voltak iparosok és kereskedők. Tanulmányomban a sütők vagy pékek, bábsütők adatait veszem számba kiegészítve a két cukrászról és a néhány gabona- és lisztkereskedőről szóló híradásokkal is. A 291 helységben mindössze 30 a sütők és 5 a pékek száma, bábos mestereké 15, cukrászoké 2 . A legtöbb bábos Kaposváron tevékenykedett három is, Marcaliban, Szigetváron, Nagyatádon, Andocson ${ }^{61}$ kettő-kettő, Szulókon, Nagyatádon, Csurgón, Nagybajomban, Somogyszilban 1 fő. Gabonakereskedésre 14-en specializálódtak, liszt árusításra mindössze 5-en. A jobbágyfelszabadítással az iparosok már nem voltak kötelesek a helyi uradalomtól vásárolni a lisztet, hanem vehettek kereskedőktől is. Pékek, sütők a városiasodó helyeken voltak többen (Szigetváron négy (két pék, két sütő), Kaposváron 3, Igalon, Nagyatádon, Tabon 2-2. Van több uradalmi központban is pékmester (Iharosberény, Berzence, Böhönye, Kéthely) és népesebb német falvakban (Szil), illetve egykori köznemesek által lakott helységekben (Nemesvid, Nemesdéd). Bábosok főként a nagyobb helységekben laktak, de két népesebb német faluban is (Szil, Szulók).

60 Récsei B. 2005. 78

61 Andocson a helyi búcsú miatt kellett, hogy bábos mesterek legyenek, már 1807-ben összeirtak a céh mesterei között egy bábost Kupits Mátyást, (szerepel Kopits néven is a család) és egy „pékné”-t „Schmidt Mihálynő”-t, aki szintén a búcsúra is készíthetett kenyeret. 1848-ban a nemzetörök között is volt egy Matizsnyi (valószínü Materényi) Ferenc 36 éves bábos, (SML Nemzetőri összeírások) 1869-ben Csík József és Materényi Ferenc működött itt. 1945-ben Petrás István, Dani Sándor (Csik leszármazott) és Ács István dolgozott itt. Csóti Cs.2002: 162-169.
Köztük már vannak horvát és magyar nevüek is. A gabona és lisztkereskedők a legforgalmasabb piaci, vásáros helyeken szerveződtek, föként Kaposváron,(5 gabona 1 lisztkereskedő) Nagyatádon (3 is), Szilban, (2 gabona, 2 lisztkereskedő), Tabon (2 gabonakereskedő), Gyalánban csak 1. Kaposvár a 20. század elején is a gabona és lisztkereskedelem legfontosabb központja volt.

A fenti összegezés nem tüntet fel vallást. A német nevüek között lehettek zsidók is, de nem nagy számban. Mindenesetre egy azonos korból való tabi összeírás, az egyik zsidók által leginkább lakott helységből mutatja, hogy a zsidók leginkább a szabómesterséget részesítették előnyben és föként a bőr kikészítésével és feldolgozásával kapcsolatos iparágakat, részben az építőipar ágait (üveges, bádogos) Tabon a pék és bábos nem volt zsidó, ${ }^{62}$ de ha nem is nagy számban, de másfelé előfordultak a pékek között is.

Az iparosok megbecsülésének számos jele lehetett. PI. szívesen hívták meg őket keresztszülőknek, mint erre Benda Gyula Keszthely kapcsán éppen sütő- és bábosmestert hozott fel példának. Arról is írt, mint mások is, hogy a sikeresebb, tekintélyesebb iparosok a városi tanácsba is bekerültek. ${ }^{63} \mathrm{Az} 1869$-es összeírás kapcsán választottak egy 44 ún „kültagot”(24 kereskedőt, 20 iparost) számláló bizottságot az új kereskedelmi és iparkamara életbe léptetéséhez. A törvény értelmében mindössze 2 iparos, 2 kereskedő kellett erre a célra. Így 44 tagnak nem lett funkciója. Számunkra érdekes, mert nyilvánvaló, hogy a legtekintélyesebbeket választották ki. Belekerült e csoportba Materényi Ferenc andocsi bábos, Nöthig József barcsi sütő, Günsberger Boldizsár nemesdédi pék is emelve szakmájuk hírnevét.

Az 1876-is iparos összeírás a pékek, bábosok és cukrászok számának jelentős emelkedését mutatja, ami a városiasodás és részben bizonyos ízlésváltozás jele. ${ }^{64}$ Nem tűntette fel név szerint az iparosokat, helységenként a segédszemélyzettel együtt. Csak az összesítést idézem, mely szerint „sütőipari vállalat” 66 müködött a megyében, (1869-ben 34). A különbség lényegében csak 11, mert az 1869-es összeírás nem vette számba a segéd nélküli műhelyeket, ami 1876-ban 21 üzem.

Az 1869-es összeírás csak részben említi a segédeket (igali járás), jóllehet adózó csak az lehetett, akinek legalább 1 legénye volt. 1876-ban már feltüntették a segédszemélyzet számát, ez 92. Alkalmazottak nélkül 21 mühely müködött, 1 segéddel 16 , 2-vel 17,3 segéddel 8,4 segéddel 2,5 segéddel 2 mühely dolgozott.

1876-ban mézesbábos 28 mühelyben dolgozott 28 fő segédszemélyzettel. 9 mester egyedül tevékenykedett, 9 műhelyben 1 segédet, 3 mühelyben 2 segédet, 3 mühelyben 3 segédet, 1 mühelyben 1 segédet alkalmaztak. Míg 1869-ben csak 13 mühelyt tartottak számon.

Cukrász, cukorsütemény készítő vállalkozást 8-at tartottak 1876-ban számon 16 segéddel, míg korábban 2 mühely volt a megyében. ${ }^{65}$

62 Csóti Cs. 2005: 31

63 Benda Gy.-Király F. 1988. 36-41. 1833-ban Pachberger Fülöpöt és nejét 13 keresztelére hívták meg, Vlasik György bábost 7 vagy 8 keresztelőre.

64 A soproni....1876:. évböl. 544-678.

65 i.m. 172-3.p. 


\section{Irodalom}

BENDA Gy. és KIRÁLY F. 1988: Iparosok egy kisváros társadalmában. Keszthely 1711-1850. - In: (ed). Nagybákay P. - Németh G. V. Kézművesipari Szimpozion Veszprém 1988. nov. 15-16. Veszprém pp. 31-45.

BúzA J. 2005: Kézművesség a három részre szakadt Magyarországon (16-17. század) - In: (ed) Szulovszky J.: A kézmüvesipar története. Magyar Kereskedelmi és Iparkamara kiadása. Budapest pp. 171-191.

BRIGHT, R. 1815/1970: Richard Bright utazásai a Dunántúlon 1815. Veszprém.

Csótı Cs. 2002: Andocs. - In (ed) Bösze S.: Száz Falu Könyvesháza. Kaposvár.

Csótı Cs. 2005: A Somogy megyei izraelita központi választmány dokumentumaiból 1868. - Somogy Megye Múltjából Levéltári Évkönyv pp. 19-76.

DóKA K. 2005: Kézműipar a török kiűzésétöl a céhek megszűntetéséig. - In: (ed) Szulovszky J. A magyar kézmüvesipar története. Budapest pp. 209-240.

Domonkos O. 1991: A kézművesség szerepe a falu anyagi kultúrájának alakításában. - In: (ed) Domonkos O. Magyar Néprajz III. Kézmüvesség. Budapest pp.7-154.

Gözsy G. 2001: Újjáéledéstől a reformkorig. - In: (ed) Bősz S. Nagyatád története I. pp. 111-137.

HoRVÁTH J. 2009: Csurgó monográfiája. Kiadta a Csurgó város önkormányzata Csurgó.

Hoss J. 1968: Méhészkedés a Nagyberekben Somogyszentpálon. - In (ed) Takáts Gy. Somogyi néphagyományok. Somogyi Múzeum Füzetei 13. pp. 26-38.

JuHÁsz A. 1991. A falu és mezőváros ellátásában jelentős kézművesség nyersanyag előállító és feldolgozó munkája. - In (ed) Domonkos O. Magyar Néprajz III. Kézmüvesség. Budapest pp.157-213

KAPITÁNY O. 1980: Adatok a mézesbáb szerepére a somogyi parasztság táplálkozásában. - In. (ed) Knézy J. Somogy néprajza. Anyagi kultúra. Kaposvár pp. 169-178.
Kıss I. 1962: Kaposvár kereskedői az 1700-as években. - Emlékkönyv a kaposvári Állami Közgazdasági Technikum jubileumáról. Kaposvár pp. 82-93.

KNÉZY J. 1972: Faépítkezésre vonatkozó 18. századi adatok Somogyból. - Ethnográfia 83. pp. 518-531.

KNÉZY J. 1984: Somogy 18. századi táplálkozástörténetéböl. Somogy Megye múltjából - Levéltári Évkönyv 15. sz. pp. 135-172.

KNÉZY J. 1991: Történelmi, tárgyi, néprajzi fejezetek Marcali és környéke népéletéböl. - In: (ed) Kanyar J. Marcali története I. Várostörténeti Tanulmányok. Marcali pp. 461-168.

KNÉZY J. 1997: Élet a Festeticsek uradalmában a 18. század utolsó harmadában, Somogy Megye Múltjából - Levéltári Évkönyv 28. sz. pp. 145-168.

KNÉZY J. 2001: Táj, népcsoportok története, müvészeti hatások. - In (ed) Kapitany O. - Imrő J. Somogy megye népművészete. - Népmüvészeti örökségünk sorozat. Kaposvár pp. 7-32.

MAGYAR E. 1984: Szántódpuszta a hódoltságtól a szabadságharcig - In: (ed) Kanyar J. Szántódi Füzetek VII. Veszprém

MıKE Gy. 1968: Népi táplálkozás Lábod községben. - In (ed) Takáts Gy. Somogyi Múzeum Füzetei 13.sz. Kaposvár pp. 5-13.

PAPP Zs. 2001: Egy Baranya megyei mezőváros, Siklós iparosai a 18. század végén. - In (ed) Szulovszky J. X. Kézműves ipartörténeti Szimpozion 2001. okt. 29-30. ipartörténeti könyvtár 2. Budapest pp. 107-138.

RÉCSEI B. 2005: Somogy megye kereskedőinek és iparosainak összeírása 1869. Forrásközlés. - Somogy Megye Múltjából Levéltári évkönyv pp. 77-179.

A SOPRONI IPARKAMARA... 1876: A Soproni Iparkamara jelentése 1876. évböl. I. k. Sopron.

SZILÁGYI M. 1998: A pékek és pékáru a 20. századi mezővárosokban. - In: (ed) Szende K. - Kücsán J. Isten áldja a tisztes ipart. Tanulmányok domonkos Ottó tiszteletére. A Soproni Múzeum kiadványai 3. Sopron pp. 423-438.

Szücs J. 1979: A szentesi kenyérről és a kenyérsütögető asszonyokról. Honismeret VII. 4. sz. pp. 52-55. 74-75.

Sütőmesterek és bábsütők 1810 és 1854 között (csak két fő név ismert 1869-ben is)

Hely
Csurgó
Iharosbereny
Berzence
Köszeg
Csurgó
Böhönye
Szigetvár
Berzence
Nemesvid
Berzence
Belezna
Berzence
Csurgó
Kanizsáról
Kőszegről
Csurgó
Csurgó
Csurgó
Csurgó

név

Rippentinger János , Schmid Dávid, (Dániel?)

Schifhorn János
Datristen János
Viola Antal

Jakob Untergasse

Kölbl József

Hanslitsek József Cseho.

Fidei Ábrahám sütő

Schifhorn János

Hutsek József Cseho.

Stevlitsek mesterhez

Hablitsek József Cseho.

Prager Maximilian

Dastristen Jakab

Bíber József

Schmid Jakab

Hanslitsek Mihály

Vanicsek Lajos

$\begin{array}{ll}\text { első adat } & \text { utolsó adat, } \\ 1810 & 1829 \\ 1811 & 1832\end{array}$

1814

1820

1821

1825

1829

1830

1837

1837

1837

1840

1844

1851

1851

1852

1854

1852

1869

1869

1843

1869 megjegyzés

pékmester

pékmester,

Nemesvidre költözött

sütő, fél taxával

sütő fél taxávalt

bábsütő

pékmester Taufersdorfból, Becsehelyre költözött pékmester 1831-től

fél taxával

fél taxával

pék féltaxával

sütőmester inassal

sütőmester

sütő. fizet szegődés, szabadulásért, vándorkönyvért

sütőmester féltaxás

pékmester

sütő, beírót fizetett

bábos mester

sütőmester 


\section{Sütőmesterek, pékek, bábsütők Somogy megyében 1869-ben}

\begin{tabular}{|c|c|}
\hline $\begin{array}{l}\text { Babócsai járás } \\
\text { Babócsa } \\
\text { Szulok }\end{array}$ & Hochstätter János sütő \\
\hline Barcs & Nőthig Josef sütő (később Nettig ) \\
\hline Csokonya & Reiser Josef sütő \\
\hline Nagyatád & $\begin{array}{l}\text { Hoch József pék } \\
\text { Novacsek József pék }\end{array}$ \\
\hline $\begin{array}{l}\text { Igali járás } \\
\text { Andocs }\end{array}$ & \\
\hline Szil & $\begin{array}{l}\text { Till Péter sütő és szatócs } \\
\text { Grósz Josef sütő }\end{array}$ \\
\hline Karád & Kreutzer György sütő \\
\hline Köttcse & Tanauf Lajos sütő \\
\hline Szabadhegy & Redl Károly sütő \\
\hline Tab & $\begin{array}{l}\text { Rott Salamon sütő mester } \\
\text { Fuhrmann sütő mester }\end{array}$ \\
\hline Kaposi járás & \\
\hline Nagybajom & $\begin{array}{l}\text { Kurcz Mihály sütő } \\
\text { Sonnenberg Josef sütő }\end{array}$ \\
\hline Vámos & Kalkbrenner János sütő \\
\hline Boglár & Grósz Móritz sütőmester \\
\hline Lengyeltóti & Vilhelm Jakab sütőmester \\
\hline Kapos városa & \\
\hline Kaposvár & $\begin{array}{l}\text { Mautner Sándor sütő } \\
\text { Nőthig Károly sütő }\end{array}$ \\
\hline & Rosenbaum Jakab sütő \\
\hline Marcali járás & \\
\hline Csurgói & Vanicsek Lajos sütő \\
\hline Berzence & $\begin{array}{l}\text { Kremzír Ignácz sütő } \\
\text { Varga György sütő }\end{array}$ \\
\hline Iharosberény & Kunstner György sütő \\
\hline Nemesvid & Büchler Albertnő sütő és szatócs \\
\hline Nemesdéd & Günzberger Károly sütőmester \\
\hline Kéthely & Dobossy Sándor sütőmester \\
\hline Marcali & $\begin{array}{l}\text { Czenek Károly sütő } \\
\text { Kalnperger Jósef sütő }\end{array}$ \\
\hline
\end{tabular}

\section{Szigetvári járás}

$\begin{array}{ll}\text { Szigetvár } & \text { Kölbl Jósef sütő } \\ & \text { Mautner Sámuel sütő } \\ & \text { Veichárd Rudolf pék } \\ & \text { Verbovetz Mátyás pék } \\ \text { Istvándi } & \text { Krausz Jakab pék } \\ \text { Sellye } & \text { Kahlenberger Jósef sütő }\end{array}$

Nagy Ferenc bábos

Eitner Edmund bábsütő

Barany László bábsütő

Csík József bábos

Materényi Ferenc bábos

Bárány Flórián bábsütő

Farkas Károly bábos

Veninger Antal bábos

Gingli János „szegény bábos”

(utódai Sőtényi bábosék szintén Kaposváron.)

Szüts János bábos (1970-es években

még dolgoztak utódai)

Hanslicsek Mihály bábsütő

Amon Sándor bábsütő

Tóth Károly bábos

Vinkovits Mihály bábsütő

Veichard János bábsütő 


\title{
Guild information about the baker masters and honey-cake-makers from 1810 until 1869
}

\author{
JUDIT KNÉZY
}

The topic of this study is the deficiency of the historical and ethnographical searches in Somogy county: the history of the baker trade and the honey-cake masters. About the baker trade we haven't got any review, but there are some publications about the data and activity of honey-cake makers based on ground memories from the middle part of the 20th century. The ethnographic collection of the Rippl Rónai Múzeum saves whole workshop from honey-cakes-master originated from some market towns of the Somogy county. There were two permanent exhibitions showing honey-cake master's workshop in the County (at Zamárdi-tájház from 1977 untill 80th, and later in Marcali Townmúzeum from 1999 until today).

The first part is about the baker and honey-cake masters of the market town Csurgó who belonged to the so called 'German' Guild, they arrived to the region between 1810 and 1869 . The study contains the known names of these masters, their origins, the organisations to were they belonged, the qualification process of becoming a master, and their guild life including quarrels, sins, the reception of their apprentices, sometimes the problems with these apprentices, the guild feast and funerals. The main source of this part was the Guild's documental detailing the partly missing or inaccurate list of masters and the financial records on demands and pay offs. These masters mostly came from Austria and the Czech-Moravian lands in the $19^{\text {th }}$ century either as already masters or they qualified themselves in Csurgó. Some German tongued masters came from other regions in Transdanubia. Among the records on the guilds master pieces there is a full detailed description of one such master piece. The honey-cake masters were mostly German tongued at first but lately there were also Slavic or Hungarian ones among them. Year after year there were only one or two baker masters working in the market town or in its vicinity. The masters leaving and entering the service of Csurgó happened so often it is hard to tell if any of them worked in the same town for generations, like the ones in Szigetvár, one of the few cities in the region. Some of the masters left for bigger towns. The low numbers of the qualified baker masters in the county can be the result of the following factors: the late urbanisation process in the region, the remaining practice of baking bread at home and the fact that the wealthier residents and the traders in bakery usually ordered these wares from baking specialist and cooksmen. The number of honey-cake masters were even fewer. The financial documents indicate that the guild of the town usually purchased candles from the masters of Kanizsa town.

The second part of the study describes the taxed baker and honey-cake masters in Somogy county: the names, their numbers and workshops, from the time of the urbanisation to the last decade of the guild area (1869). The places were several masters worked simultaneously were important marketing towns or estates of the nobles. These baker masters were also mostly Germans, while the honey-cake makers were Germans, Slavic and Hungarian ones, or they bore Hungarian names. 